\title{
Smoking and periodontal tissues: a review*
}

João Batista César Neto Ecinele Francisca Rosa Cláudio Mendes Pannuti Giuseppe Alexandre Romito

Department of Stomatology, School of Dentistry, Univ of São Paulo, São Paulo, SP, Brazil.
* Paper presented at the "Oral Health Promotion: Expanding the Boundaries of Knowledge" International Symposium, held at the $16^{\text {th }}$ Congress of the Brazilian Association for Oral Health Promotion (ABOPREV), June 30 to July 2, 2011, Brasília, DF, Brazil.

Declaration of Interests: The authors certify that they have no commercial or associative interest that represents a conflict of interest in connection with the manuscript.

Corresponding Author:

João Batista César Neto

E-mail: jbcesarneto@usp.br

Submitted: Oct 04, 2011

Accepted for publication: Dec 14, 2011

Last revision: Aug 20, 2012
Abstract: The impact of smoking on general health has been widely studied and is directly related to several important medical problems including cancer, low birth weight, and pulmonary and cardiovascular disease. In the past 25 years, there has also been an increasing awareness of the role of cigarette consumption in oral health problems such as periodontal disease. Smoking is considered the major risk factor in the prevalence, extent and severity of periodontal diseases. This article will discuss the available evidence and provide the reader with an overview of the impact of smoking and its cessation on the pathogenesis and treatment of periodontal diseases.

Descriptors: Smoking Cessation; Smoking; Tobacco; Periodontitis; Periodontal Disease.

\section{Introduction}

It is estimated that tobacco use kills more than 5 million people per year. This means 1 in every 10 adult deaths worldwide. Smoking is a common risk factor in a number of chronic diseases, including cancer, lung diseases and cardiovascular diseases. ${ }^{1}$

Smoking is the major risk factor in the prevalence, extent and severity of periodontal diseases. ${ }^{2-5}$ Cross-sectional studies have shown that smokers are two to seven times more likely to present periodontitis, compared to nonsmokers, ${ }^{2,6,7}$ and smoking has been associated with tooth loss during periodontal maintenance as well. ${ }^{7,8}$

With respect to surgical or non-surgical periodontal therapy, several studies have shown that smokers have a worse response to treatment when compared to nonsmokers. ${ }^{9,10}$

In southern Brazil, ${ }^{6}$ it has been estimated that smoking cessation programs could result in an approximate reduction of up to $12 \%$ in the number of cases of destructive periodontal disease (cases were defined as individuals with $\geq 30 \%$ of teeth with periodontal attachment loss $\geq 5 \mathrm{~mm}$ ). These statements draw attention to the extreme importance of implementing population-based smoking cessation programs both to increase general health (common risk factor approach) ${ }^{11}$ and to decrease the prevalence of severe periodontal diseases in heavy smokers.

Owing to the significant impact of smoking on periodontal health, this study aimed at reviewing the literature regarding the negative effects of smoking on periodontal tissues, emphasizing the importance of smoking cessation to improve periodontal health and to benefit from the 
results of periodontal treatment.

\section{Smoking and periodontal tissues Epidemiological studies}

In the 1980s and 1990s several epidemiological studies established an association between smoking and destructive periodontal disease. ${ }^{12-15}$

Risk assessment based on an increasing body of investigations over the past few years suggests that tobacco-attributable risk odds ratios (OR) range between 2.5 and $6.0^{7,15,16}$ or are even over 6.0 in heavy smokers (e.g., $>20$ cigarettes/day). ${ }^{15}$

The findings provided by Tomar and Asma, ${ }^{7}$ based on data from the NHANES III study, may be considered a strong body of evidence of smoking as a risk factor for periodontal diseases. In this study 12,329 subjects were evaluated, and the authors suggested that approximately half of the periodontitis cases in the USA could be attributed to smoking. In addition, they observed that current smokers were about 4 times more likely to be diagnosed with periodontitis than never-smokers, and that there was a dose-response relationship between the number of cigarettes smoked per day and the odds of periodontitis.

Clinical studies have demonstrated that smokers have more severe periodontal disease, with increased bone loss, ${ }^{17,18}$ greater periodontal attachment loss, more gingival recession and periodontal pocket formation. ${ }^{19}$ A patient's history of smoking has been associated with early attachment loss in adults. ${ }^{20}$ In another study, cigarette smoking was considered a strong predictor of progressive periodontitis. ${ }^{21}$ Linden and Mullally ${ }^{22}$ found the odds ratio for periodontal disease to be as high as 14.1 for young smokers.

Brazilian epidemiological studies have also demonstrated this association. Susin et al. ${ }^{6}$ evaluated a representative sample of the Porto Alegre population (Rio Grande do Sul State, Brazil) and observed that smokers with moderate and strong dependence had 2.0 and 3.6 more risk, respectively, of having clinical attachment loss $\geq 5 \mathrm{~mm}$ than subjects who did not smoke. In another investigation, Lima et al. ${ }^{23}$ concluded that smoking enhances bone loss resulting from periodontitis.
Recent studies have also suggested that passive smoking may be associated with periodontal diseases. ${ }^{24-26}$ Erdemir et al. ${ }^{25}$ evaluated 109 children (range 6-12 years), classified as either exposed to passive tobacco $(\mathrm{n}=51)$ or as unexposed $(\mathrm{n}=58)$. The authors showed higher cotinine levels and greater attachment loss in passive smokers, when compared to unexposed children. Nishida et al. ${ }^{26}$ conducted a 2-year longitudinal study and observed that passive smoking increases the salivary levels of albumin, aspartate aminotransferase and lactoferrin. The authors suggested that passive smoking may affect inflammatory response and may be associated with a greater risk for periodontitis progression. Although additional studies are necessary, it seems that passive smoking also affects periodontal health negatively.

\section{Biological effects and events}

Although the association between smoking and periodontal disease has been extensively demonstrated through epidemiological studies, the mechanisms by which smoking contributes to the pathogenesis of periodontitis have not yet been totally understood.

It has been reported that smokers may present a significantly greater plaque index and that the average number of bleeding sites in smokers $(27 \%)$ is smaller than in nonsmokers $(40 \%) .{ }^{27}$ Microbiological studies showed that smokers had a higher prevalence of bacterial species related to periodontal disease compared to nonsmokers, including Porphyromonas gingivalis, Aggregatibacter actinomycetencomitans, Bacteroides forsythus, ${ }^{28}$ Prevotella intermedia, Fusobacterium nucleatum. However, some authors reported no differences between smokers and nonsmokers with respect to the detection of periodontal pathogens, ${ }^{29,30}$ both in terms of prevalence $^{31}$ and amount of bacteria ${ }^{32}$ in the subgingival microbiota. Recent studies, using real time PCR, have demonstrated a positive relationship between degree of smoking and amount of bacteria/probing depth. ${ }^{33,34}$

The influence of smoking on experimental gingivitis was evaluated in a group of dental students ${ }^{35}$ (the volunteers were free of periodontitis and not 
on any medication, and the group of smokers had been smoking for at least four years). This study revealed that the number of gingival bleeding sites, the amount of gingival exudate and the number of gingival sites with distinct redness were significantly lower in smokers than in nonsmokers with comparable levels of plaque indexes. Bergstrom et al. ${ }^{36}$ found that the intensity of vascular reaction after 28 days of plaque-induced gingivitis in smokers was only $50 \%$ of that observed in nonsmokers.

The preponderance of evidence suggests that smoking may decrease gingival bleeding and that this may occur owing to changes in the proportion of blood vessels in the periodontal tissues. ${ }^{37}$

As an attempt to determine the mechanisms involved in smoking modulation of the periodontal tissues, in vitro and in vivo studies have investigated the impact of cigarette compounds, including nicotine and cotinine, on the periodontal tissues. In general, nicotine has been reported to adversely affect proliferation, attachment and chemotaxis of periodontal ligament cells, and induce pro-inflammatory cytokine production by human gingival fibroblasts synergistically with lipopolysaccharide from Escherichia coli and P. gingivalis. ${ }^{38-40}$

In a rat model, the impact of cigarette compounds on the periodontal tissues showed a greater bone loss in the ligated teeth of the groups that received nicotine when compared to the control group..$^{41,42}$ This evidence suggests that nicotine alone could affect periodontal bone loss resulting from periodontitis. ${ }^{41,42}$

Nicotine is just one of the toxic compounds of cigarette smoke. A passive smoking model was devised with the objective of investigating the impact of cigarette smoke as a whole on periodontal tissues. ${ }^{43}$ It was demonstrated that cigarette smoke inhalation (CSI) enhances periodontal bone destruction in ligature-induced periodontitis. An additional analysis of gingival tissue adjacent to periodontitis sites showed that matrix metalloproteinase (MMP)2 levels were higher in the exposed versus non-exposed animals. This finding suggests that MMP-2 may be one of the molecules responsible for the increased tissue degradation observed in the periodontal tissues of smokers. ${ }^{43}$ In general, these results suggest that nicotine seems to be a key molecule for the intensified periodontal destruction observed in smokers and may contribute, at least partially, to the negative impact of cigarette smoke as a whole.

Although a number of studies have considered smoking as a true risk factor for periodontitis, the mechanisms involved are still not clear. In an in vitro study, nicotine, both in and not in association with lipopolysaccharide (LPS) from periodontopathogenic bacteria, was shown to increase IL- 6 and IL- 8 protein production by human gingival fibroblasts. ${ }^{40}$ A microarray analysis demonstrated that peripheral blood mononuclear cells exposed for 5 minutes to tobacco smoke presented an elevated expression of 20 genes previously reported to be associated with periodontal pathogenesis. ${ }^{44}$

Higher levels of TNF- $\alpha$ and IL- 8 were observed in the gingival crevicular fluid of smokers compared to nonsmokers. ${ }^{45}$ In contrast, pro- and anti-inflammatory cytokines have been reported to be lower in association with smoking and its compounds. It seems that cigarette smoke contains potent inhibitors of both gene expression and protein production, at least for IL-1 $\beta$, IL-8, IL-2 and TNF- $\alpha .{ }^{46}$

Although significant, these studies do not provide an accurate description of the underlying mechanisms by which smoking affects the periodontium. In order to investigate possible mechanisms involved in the smoking modulation of periodontal attachment loss, César-Neto et al. investigated the profile of a number of pro- and anti-inflammatory cytokines plus pro- and anti-resorptive agents in the gingival tissues of smokers versus nonsmokers with moderate to severe chronic periodontitis. The following molecules were evaluated:

- IL-1 $\beta$,

- IL-1ra,

- IL-6,

- IL-8,

- IL-10,

- interferon (INF)- $\gamma$,

- TNF- $\alpha$,

- MMP-2 and -8,

- receptor activator of NF-KB ligand (RANKL) and

- osteoprotegerin (OPG). ${ }^{47,48}$ 
With respect to smoking modulation on gene expression, it was found that IL-1 $\beta$, IL-8, IL-10, TNF- $\alpha$, MMP- 8 and OPG were lower in smokers than nonsmokers, whereas IL-6, IL-1 $\mathrm{ra}^{47}$ and INF- $\gamma^{48}$ were higher. Increased RANKL:OPG and IL-6:IL-10 ratios were found in sites with periodontitis in smokers versus nonsmokers, whereas the $1 \beta:$ IL-1ra ratio in smokers was similar to that observed in the healthy group ${ }^{47}$ It was then concluded that smoking modulation of bone destruction in periodontal disease may involve reduced levels of anti-inflammatory and anti-resorptive factors such as IL-10 and OPG, respectively, and may also involve high levels of pro-inflammatory cytokines such as IL- 6 and INF- $\gamma{ }^{47}$

\section{Periodontal treatment in smokers}

It has been demonstrated that smoking has an adverse influence on all forms of periodontal therapy, and that up to $90 \%$ of refractory periodontitis patients are smokers. ${ }^{49}$

In the periodontal field, a number of clinical studies have compared the response of smokers and nonsmokers to various types of periodontal therapy, including both non-surgical and surgical therapies. ${ }^{50}$ Most of the studies show significantly greater reductions in probing depths and bleeding on probing, and a significantly greater gain of clinical attachment after non-surgical and surgical treatments in nonsmokers, compared to smokers. ${ }^{51} \mathrm{~A}$ similar scenario is observed in the treatment of furcation regions $^{52}$ and after regenerative procedures. ${ }^{53}$

Recent studies have suggested that the adjunct use of local and systemic antimicrobial therapy may improve the clinical results obtained with scaling/ root planing ${ }^{54}$ and guided tissue regeneration in smokers. ${ }^{55}$ Machion et al. ${ }^{56,57}$ showed that the association of scaling and root planing to local $10 \%$ doxycycline in the treatment of smokers with chronic periodontitis may lead to better clinical results than mechanical therapy alone.

Microbiological examination of these patients revealed that the adjunct use of locally delivered doxycycline after scaling and root planing may favor the elimination of $T$. forsythensis and $P$. gingivalis in a greater proportion of sites than conventional me- chanical therapy. ${ }^{58}$ These studies provide valuable information for dealing with the limitations of periodontal therapy in smokers.

\section{Smoking cessation and periodontal tissues}

There is clinical and histological evidence demonstrating that the negative effect of smoking on periodontal tissues may be reverted after quitting smoking. A histological study in rats showed that the interruption of smoke exposure would reverse the negative impact of cigarette smoke inhalation (CSI) on periodontitis-related bone loss. ${ }^{59}$ Additionally, this study radiographically investigated the effect of CSI on mandibular bone quality. ${ }^{59}$ The results revealed similar levels of bone loss for both the control and cessation groups, while the group continuously exposed to CSI presented significantly increased periodontal destruction.

Moreover, the radiographic findings regarding bone quality may be of particular relevance in the field of clinical implantology, since bone quality and smoking are well recognized factors associated with clinical implant failures. A complementary study was performed to confirm the radiographic findings and to investigate whether the figure observed for the basal mandibular bone would also occur in the tooth supporting alveolar bone. ${ }^{60}$ Data analysis showed that animals continuously exposed to cigarette smoke inhalation presented a decreased proportion of mineralized tissue, when compared to the control and cessation groups, while both control and cessation groups presented similar results. These findings confirm the previous data regarding the mandibular basal bone showing a beneficial effect of smoking cessation on mandibular bone quality.

It is unclear how long after smoking interruption the body recovers its normal inflammatory conditions. Domagala-Kulawik ${ }^{61}$ reported that even after smoking cessation, many changes in the immune system (caused by tobacco) are still present. On the other hand, Bouloukaki et al. ${ }^{62}$ suggested that, there is an increase of $\mathrm{CD} 8^{+} \mathrm{T}$-cells and a decrease of the $\mathrm{CD}^{+} / \mathrm{CD}^{+}{ }^{+}$within 6 months after smoking cessation. Morozumi et al. ${ }^{46}$ state that it takes more than 8 weeks for levels of IL- $1 \beta$, IL- 8 , TNF- $\alpha$ and VEGF 
to return to their normal values, and that the role (or function) of neutrophils is still not completely recovered after this period.

Morozumi et al. ${ }^{63}$ and Nair et al. ${ }^{64}$ reported an increase in gingival blood flow after smoking cessation, as observed with Laser Doppler flowmetry.

Fullmer et al. ${ }^{65}$ conducted a 12 -month longitudinal study that revealed the crucial role of smoking cessation in changing the subgingival biofilm and, consequently, the response to periodontal treatment. In this study, the authors concluded that smoking cessation promoted changes in the subgingival ecosystem, featured by changes in the levels of microbial species.

With respect to mechanical periodontal treatment, there are just two interventional clinical studies evaluating the benefits of quitting smoking on periodontal conditions after treatment. ${ }^{66,67}$ Both studies (one performed in the United Kingdom ${ }^{66}$ and the other performed in Brazil $)^{67}$ conducted a 12-month prospective evaluation that assessed the adjunctive effect of smoking cessation on the nonsurgical periodontal therapy of subjects with severe chronic periodontitis. Preshaw et al. ${ }^{66}$ evaluated 49 smokers intending to quit smoking. All participants received non-surgical periodontal treatment and

\section{References}

1. World Health Organization. [Internet]. Geneve: WHO; 2010 [cited 2010 Oct 18]. Available from: http://www.who.int/fctc/ press.pdf.

2. Albandar JM. Global risk factors and risk indicators for periodontal diseases. Periodontol 2000. 2002;29(1):177-206.

3. Burt B, Research, Science and Therapy Committee of the American Academy of Periodontology. Position paper: epidemiology of periodontal diseases. J Periodontol. 2005 Aug;76(8):1406-19.

4. Luzzi LI, Greghi SL, Passanezi E, Sant'ana AC, Lauris JR, Cestari TM. Evaluation of clinical periodontal conditions in smokers and non-smokers. J Appl Oral Sci. 2007 Dec;15(6):512-7

5. Oppermann RV. An overeview of the epidemiology of periodontal diseases in Latin America. Braz Oral Res. 2007 Apr;21(Spec Iss 1):8-15.

6. Susin C, Oppermann RV, Haugejorden O, Albandar JM. Periodontal attachment loss attributable to cigarette smoking smoking cessation therapy according to their individual needs. The authors concluded that smoking cessation promoted an additional benefit in reducing probing depth after non-surgical periodontal treatment. Rosa et al. ${ }^{67}$ observed similar findings in a similar experimental design and with a sample ( $\mathrm{n}=93$ subjects) larger than that used by Preshaw et al. ${ }^{66}(\mathrm{n}=49)$. Rosa et al. ${ }^{67}$ concluded that smoking cessation promoted clinical attachment gain after a one-year follow-up, in the quitters' group only. In addition, the magnitude of clinical attachment gains of sites initially $>4 \mathrm{~mm}$ was significantly greater in the quitters' group.

\section{Conclusion}

In light of the existing evidence, it can be concluded that smoking is a strong risk factor for periodontal diseases. The mechanisms by which tobacco use favors periodontal destruction still need complementary investigation to be better understood. It seems that a down-regulation of anti-inflammatory factors associated with an up-regulation of proinflammatory cytokines is involved. In addition, smoking cessation is the main option to revert the harmful effects of tobacco on periodontal risk and therapy.

in an urban Brazilian population. J Clin Periodontol. 2004 Nov;31(11):951-8.

7. Tomar SL, Asma S. Smoking-atributable Periodontitis in the United States: findings from NHANES III. National Health and Nutrition Examination Survey. J Periodontol. 2000 May;71(5):743-51.

8. Chambrone L, Chambrone D, Lima LA. Predictors of tooth loss during long-term periodontal maintenance: a systematic review of observational studies. J Clin Periodontol. 2010 Jul;37(7):675-84.

9. Labriola A, Needleman I, Moles DR. Systematic review of the effect of smoking on nonsurgical periodontal therapy. Periodontol 2000. 2005;37(1):124-37.

10. Wan CP, Leung WK, Wong MC, Wong RM, Wan P, Lo EC, et al. Effects of smoking on healing response to non-surgical periodontal therapy: a multilevel modelling analysis. J Clin Periodontol. 2009 Mar;36(3):229-39. 
11. Sheiham A, Watt RG. The common risk factor approach: a rational basis for promoting oral health. Community Dent Oral Epidemiol. 2000 Dec;28(6):399-406.

12. Bergstrom J, Eliasson S. Noxious effect of cigarette smoking on periodontal health. J Periodontal Res. 1987 Nov;22(6):5137.

13. Bergstrom, J. Cigarette smoking as risk factor in chronic periodontal disease. Community Dent Oral Epidemiol. 1989 Oct;17(5):245-7.

14. Goultschin J, Cohen HD, Donchin M, Brayer L, Soskolne WA. Association of smoking with periodontal treatment needs. J Periodontol. 1990 Jun;61(6):364-7.

15. Norderyd O, Hugoson A, Grusovin G. Risk of severe periodontal disease in a Swedish adult population. A longitudinal study. J Clin Periodontol. 1999 Sep;26(9):608-15.

16. Gelskey SC, Young TK, Singer DL. Factors associated with adult periodontitis in a dental teaching clinic population. Community Dent Oral Epidemiol. 1998 Aug;26(4):226-32.

17. Bergström J, Eliasson S, Dock J. A 10-year prospective study of tobacco smoking and periodontal health. J Periodontol. 2000 Aug;71(8):1338-47.

18. Bergström J, Eliasson S, Dock J. Exposure to tobacco smoking and periodontal health. J Clin Periodontol. 2000 Jan;27(1):618.

19. Calsina G, Ramón JM, Echeverría JJ. Effects of smoking on periodontal tissues. J Clin Periodontol. 2002 Aug;29(8):771-6.

20. Tanner AC, Kent R Jr, Van Dyke T, Sonis ST, Murray LA. Clinical and other risk indicators for early periodontitis in adults. J Periodontol. 2005 Apr;76(4):573-81.

21. Heitz-Mayfield LJ. Disease progression: identification of highrisk groups and individuals for periodontitis. J Clin Periodontol. 2005;32 Suppl 6:196-209.

22. Linden GJ, Mullally BH. Cigarette smoking and periodontal destruction in young adults. J Periodontol. 1994 Jul;65(7):71823.

23. Lima FR, Cesar-Neto JB, Lima DR, Kerbauy WD, NogueiraFilho GR. Smoking enhances bone loss in anterior teeth in a Brazilian population: a retrospective cross-sectional study. Braz Oral Res. 2008 Oct-Dec;22(4):328-33.

24. Brook I. The impact of smoking on oral and nasopharyngeal bacterial flora. J Dent Res. 2011 Jun;90(6):704-10.

25. Erdemir EO, Sönmez IS, Oba AA, Bergstrom J, Caglayan O. Periodontal health in children exposed to passive smoking. J Clin Periodontol. 2010 Feb;37(2):160-4.

26. Nishida N, Yamamoto Y, Tanaka M, Kataoka K, Kuboniwa M, Nakayama K, et al. Association between involuntary smoking and salivary markers related to periodontitis: a 2-year longitudinal study. J Periodontol. 2008 Dec;79(12):2233-40.

27. Preber H, Bergstrom J. Occurrence of gingival bleeding in smoker and non-smoker patients. Acta Odontol Scand. 1985 Oct;43(5):315-20.

28. Zambon JJ, Grossi SG, Matchtei EE, Ho AW, Dunford R, Genco RJ. Cigarette smoking increases the risk for subgingival infection with periodontal pathogens. J Periodontol. 1996 Oct;67(10 Suppl):1050-4.

29. Apatzidou DA, Riggio MP, Kinane DF. Impact of smoking on the clinical, microbiological and immunological parameters of adult patients with periodontitis. J Clin Periodontol. 2005 Sep;32(9):973-83.

30. Salvi GE, Ramseier CA, Kandylaki M, Sigrist L, Awedowa E, Lang NP. Experimental gingivitis in cigarette smokers: a clinical and microbiological study.J Clin Periodontol. 2005 May;32(5):441-7.

31. Darby IB, Hodge PJ, Riggio MP, Kinane DF. Microbial comparison of smoker and non-smoker adult and early-onset periodontitis patients by polymerase chain reaction. J Clin Periodontol. 2000 Jun;27(6):417-24.

32. Stoltenberg JL, Osborn JB, Pihlstrom BL, Herzberg MC, Aeppli DM, Wolff LF, et al. Association between cigarette smoking, bacterial pathogens and periodontal status. J Periodontol. 1993 Dec;64(12):1225-30.

33. Gomes SC, Piccinin FB, Oppermann RV, Susin C, Nonnenmacher CI, Mutters R, et al. Periodontal status in smokers and never-smokers: clinical findings and real-time polymerase chain reaction quantification of putative periodontal pathogens. J Periodontol. 2006 Sep;77(9):1483-90.

34. Teixeira SRL, Mattarazo F, Feres M, Figueiredo LC, de Faveri M, Simionato MR, et al. Quantification of Porphyromonas gingivalis and fimA genotypes in smoker chronic periodontitis. J Clin Periodontol. 2009 Jun;36(6):482-7.

35. Bergstrom J, Preber H. The influence of cigarette smoking on the development of experimental gingivitis. J Periodontal Res. 1986 Nov;21(6):668-76.

36. Bergstrom J, Persson L, Preber H. Influence of cigarette smoking on vascular reaction during experimental gingivitis. Scand J Dent Res. 1988 Feb;96(1):34-9.

37. Rezavandi K, Palmer RM, Odell EW, Scott DA, Wilson RF. Expression of ICAM-1 and E-selectin in gingival tissues of smokers and non-smokers with periodontitis. J Oral Pathol Med. 2002 Jan;31(1):59-64.

38. Giannopoulou C, Geinoz A, Cimasoni G. Effects of nicotine on periodontal ligament fibroblasts in vitro. J Clin Periodontol. 1999 Jan;26(1):49-55.

39. Giannopoulou C, Roehrich N, Mombelli A. Effect of nicotine-treated epithelial cells on the proliferation and collagen production of gingival fibroblasts. J Clin Periodontol. 2001 Aug;28(8):769-75.

40. Wendell KJ, Stein SH. Regulation of cytokine production in human gingival fibroblasts following treatment with nicotine and lipopolysaccharide. J Periodontol 2001;72(8):1038-1044.

41. Nociti FH Jr, Nogueira-Filho GR, Primo MT, Machado MA, Tramontina VA, Barros SP, et al. The influence of nicotine on the bone loss rate in ligature-induced periodontitis. A histometric study in rats. J Periodontol. 2000 Sep;71(9):1460-4.

42. Nociti FH Jr, Nogueira-Filho GR, Tramontina VA, Machado MA, Barros SP, Sallum EA, et al. Histometric evaluation of the 
effect of nicotine administration on periodontal breakdown: an in vivo study. J Periodontal Res. 2001 Dec;36(6):361-6.

43. César Neto JB, de Souza AP, Barbieri D, Moreno H Jr, Sallum EA, Nociti FH Jr. Matrix metalloproteinase-2 may be involved with increased bone loss associated with experimental periodontitis and smoking: a study in rats. J Periodontol. 2004 Jul;75(7):995-1000.

44. Ryder MI, Hyun W, Loomer P, Haqq C. Alteration of gene expression profiles of peripheral mononuclear blood cells by tobacco smoke: implications for periodontal diseases. Oral Microbiol Immunol 2004;19(1):39-49.

45. Giannopoulou C, Cappuyns I, Mombelli A. Effect of smoking on gingival crevicular fluid cytokine profile during experimental gingivitis. J Clin Periodontol. 2003 Nov;30(11):996-1002.

46. Morozumi T, Kubota T, Sugita N, Itagaki M, Yoshie H. Alterations of gene expression in human neutrophils induced by smoking cessation. J Clin Periodontol 2004;31(12):1110-1116.

47. César-Neto JB, Duarte PM, de Oliveira MC, Tambeli CH, Sallum EA, Nociti FH Jr. Smoking modulates IL-6:IL-10 and RANKL:OPG ratios in the periodontal tissues. J Periodontal Res. 2007 Apr;42(2):184-91.

48. César-Neto JB, Duarte PM, de Oliveira MC, Casati MZ, Tambeli CH, Parada CA, Sallum EA, Nociti FH Jr. Smoking modulates INF- $\gamma$ expression in the gingival tissues of patients with chronic periodontitis. Eur J Oral Sci 2006 Oct;114(5):403-8.

49. Magnusson I, Walker CB. Refractory periodontitis or recurrence of disease. J Clin Periodontol. 1996 Mar;23(3 Pt 2):28992.

50. Johnson GK, Hill M. Cigarette smoking and the periodontal patient. J Periodontol 2004;75(2):196-209.

51. Heasman L, Stacey F, Preshaw PM, McCracken GI, Hepburn $S$, Heasman PA. The effect of smoking on periodontal treatment response: a review of clinical evidence. J Clin Periodontol. 2006 Apr;33(4):241-53.

52. Dannewitz B, Krieger JK, Hüsing J, Eickholz P. Loss of molars in periodontally treated patients: a retrospective analysis five years or more after active periodontal treatment. J Clin Periodontol. 2006 Jan;33(1):53-61.

53. Bowers GM, Schallhorn RG, McClain PK, Morrison GM, Morgan R, Reynolds MA. Factors influencing the outcome of regenerative therapy in mandibular Class II furcations: Part I. J Periodontol. 2003 Sep;74(9):1255-68.

54. Preshaw PM, Hefti AF, Bradshaw MH. Adjunctive subantimicrobial dose doxycycline in smokers and non-smokers with chronic periodontitis. J Clin Periodontol. 2005 Jun;32(6):6106.

55. Machtei EE, Oettinger-Barak O, Peled M. Guided tissue regeneration in smokers: effect of aggressive anti-infective therapy in Class II furcation defects. J Periodontol. 2003 May;74(5):579-84.

56. Machion L, Andia DC, Benatti BB, Carvalho MD, NogueiraFilho GR, Casati MZ, et al. Locally delivered doxycycline as an adjunctive therapy to scaling and root planing in the treatment of smokers: a clinical study. J Periodontol. 2004 Mar;75(3):464-9.

57. Machion L, Andia DC, Lecio G, Nociti FH Jr, Casati MZ, Sallum AW, et al. Locally delivered doxycycline as an adjunctive therapy to scaling and root planing in the treatment of smokers: a 2-year follow-up. J Periodontol. 2006 Apr;77(4):606-13.

58. Machion L, Andia DC, Saito D, Klein MI, Gonçalves RB, Casati MZ, et al. Microbiological changes with the use of locally delivered doxycycline in the periodontal treatment of smokers. J Periodontol. 2004 Dec;75(12):1600-4.

59. César-Neto JB, Benatti BB, Neto FH, Sallum AW, Sallum EA, Nociti FH. Smoking cessation may present a positive impact on mandibular bone quality and periodontitis-related bone loss: a study in rats. J Periodontol. 2005 Apr;76(4):520-5.

60. César-Neto JB, Benatti BB, Sallum EA, Casati MZ, Nociti FH Jr. The influence of cigarette smoke inhalation and its cessation on the tooth-supporting alveolar bone: a histometric study in rats. J Periodontal Res. 2006 Apr;41(2):118-23.

61. Domagala-Kulawik J. Effects of cigarette smoke on the lung and systemic immunity.J Physiol Pharmacol. 2008 Dec;59 Suppl 6:19-34.

62. Bouloukaki I, Tsoumakidou M, Vardavas CI, Mitrouska I, Koutala E, Siafakas NM, et al. Maintained smoking cessation for 6 months equilibrates the percentage of sputum CD8+ lymphocyte cells with that of nonsmokers. Mediators of Inflamm. 2009;2009:812102.

63. Morozumi T, Kubota T, Sato T, Okuda K, Yoshie H. Smoking cessation increases gingival blood flow and gingival crevicular fluid. J Clin Periodontol. 2004 Apr;31(4):267-72.

64. Nair P, Sutherland G, Palmer RM, Wilson RF, Scott DA. Gingival bleeding on probing increases after quitting smoking. J Clin Periodontol. 2003 May;30(5):435-7.

65. Fullmer SC, Preshaw PM, Heasman PA, Kumar PS. Smoking cessation alters subgingival microbial recolonization. J Dent Res. 2009 Jun;88(6):524-8.

66. Preshaw PM, Heasman L, Stacey F, Steen N, McCracken GI, Heasman PA. The effect of quitting smoking on chronic periodontitis. J Clin Periodontol. 2005 Aug;32(8):869-79.

67. Rosa EF, Corraini P, de Carvalho VF, Inoue G, Gomes EF, Lotufo JP, et al. A prospective 12-month study of the effect of smoking cessation on periodontal clinical parameters. J Clin Periodontol. 2011 Jun;38(6):562-71. 